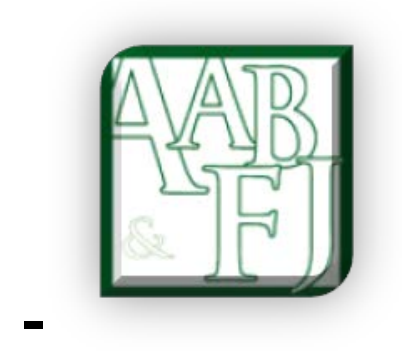

\title{
Diversity in Risk Communication
}

\author{
Agung Nur Probohudono¹, Greg Tower*2 and Rusmin²
}

\begin{abstract}
This study analyses the communication of the five major categories of risk (business, strategy, market and credit risk disclosure) over the volatile 2007-2009 Global Financial Crisis (GFC) time period in key South East Asian countries' manufacturing listed companies. This study is important as it contributes to the literature by providing insights into the voluntary risk disclosure practices using sample countries with different economic scenarios. Key findings are that business risk is the most disclosed category and strategy risk is the least disclosed. Business and credit risk disclosure consistently increase over the three year period, while operating, market and strategy risk disclosure increase in 2008, but then decrease slightly in 2009. Statistical analysis reveals that country of incorporation and size help predict risk disclosure levels. The overall low disclosure levels (26$29 \%$ ) highlight the potential for far higher communication of key risk factors.
\end{abstract}

Keywords: Voluntary risk disclosure, Asia, Agency theory, Annual Reporting.

\section{JEL Classification:G34}

\footnotetext{
${ }^{1}$ Faculty of Economics, Universitas Sebelas Maret, Solo, Indonesia.

${ }^{2}$ School of Accounting Curtin University, Perth, Australia.

* Corresponding author: Greg Tower, G.Tower@curtin.edu.au
} 


\section{Introduction}

The financial crisis of 2007-2009 represents the most serious slowdown the world economy has experienced since the Great Depression (Loser 2009). The collapse of a global housing bubble, which peaked in the United States (U.S.) in 2006, caused the value of securities tied to real estate pricing to plummet, thereafter damaging financial institutions globally (Kenc and Dibooglu 2009). Mishkin (2011) states that the financial crisis of 2007-2009 can be divided into two different phases in the U.S. The first phase is from August 2007 to August 2008 with major losses in the U.S. financial sub-prime residential mortgages. Although this troubled the U.S. financial markets, real GDP in the U.S. continued to rise into the second quarter of 2008, but in mid-September 2008 the financial crisis entered the more serious phase. Key events were: the investment bank Lehman Brothers entered bankruptcy on 15 September 2008; the insurance firm AIG collapsed on 16 September 2008; there was a run on the Reserve Primary Fund money market fund on the same day; and the U.S. government began to publicise the Troubled Asset Relief Program (TARP) (Mishkin 2011). What started as a credit crunch in July 2007 in the U.S. spread to other countries and brought the global financial system to a perceived large-scale crisis. While the crisis quickly resulted in a deep recession in a number of advanced economies, the emerging markets and developing economies were also seriously affected, but the impact varied across regions and countries (Kenc and Dibooglu 2009). Economies worldwide slowed during this period as credit tightened and international trade declined (Claessens et al. 2010).

This study examines the impact of the Global Financial Crisis (GFC) of 2007-2009 on the key sub-categories of risk disclosure via a longitudinal dataset of listed manufacturing companies in 180 annual reports in four countries (Indonesia, Malaysia, Singapore and Australia). An examination of the manufacturing sector is important as the value added to the GDP from this sector in these countries is high (Australia 29\%, Indonesia 47\%, Malaysia 55\% and Singapore 26\%), based on the database from the World Bank (2011). 2007 is the first true year of the global financial crisis, 2008 is arguably the worst year, and 2009 is the year of early crisis recovery (IMF 2009). This study is important as it helps us judge the impact of the GFC and other key factors upon the extent of risk disclosures in this weak economic timeframe. The primary research questions of this study are to explain the extent of risk disclosure in five key major categories (business, strategy, market and credit risk disclosure), and to explore the predictors of such communication.

Risk reporting and disclosures are becoming a greater concern of international accounting standard-setters (Cabedo and Tirado 2004; Atan and Maruhun 2009). For example, the International Accounting Standards Board (IASB 2008) under IAS 1: Presentation of Financial Statement and IAS 32: Financial Instruments: Presentation requires companies to provide information on principal uncertainties faced and disclosures of information for some specific risks. ${ }^{3}$ IFRS 7 regulates financial instrument: disclosures. Further, the Financial Accounting Standard Board (FASB 1998), under SFAC No. 133 establishes compulsory disclosures of market risks arising from the use of financial assets. However, as the vast majority of (non-bank) risk disclosures remain purely voluntary in contemporary times, this paper focuses exclusively on voluntary risk disclosure.

Hill and Short (2009) suggest that risk disclosures will reduce information asymmetry for firms. The concept of asymmetry between management (agents) and investors (principals) is that some information will be given but some will be withheld. A reduction in information asymmetry leads to lower monitoring costs between agents and principals (Jensen and Meckling 1976). Agents are assumed to have incentives to disclose information voluntarily, mainly driven by rational agents' self-interest regarding their reputation and remuneration (Healy and Palepu 2001). Disclosures can reduce agency costs by minimising the capacity of managers to adjust disclosure

\footnotetext{
${ }^{3}$ IAS 1 requires companies to disclose: financial risk management objectives and policies; management's judgements in determining when substantially all the significant risks and rewards of ownership of financial assets and lease assets are transferred to other entities; and information about the key assumptions concerning the future, and other key sources of estimation uncertainty at the end of the reporting period that have a significant risk of causing a material adjustment to the carrying amounts of assets and liabilities within the next financial year (IASB 2008).
} 
data (Marshall and Weetman 2002). In addition, disclosures can reduce estimation risk to better avoid market failure and increase market liquidity leading to more efficient capital markets (Healy and Palepu 2001).

A better level of risk communication allows capital market participants to be aware of potential material changes, and in doing so, these disclosures can reduce agency costs. Arguably, the disclosure of information about risk will improve stakeholder understanding: the company (using internal data) can directly communicate the various risks it faces. This higher level of transparency will greatly ease the task of interpreting the risks of the company by external users (Jensen and Meckling 1976; Cabedo and Tirado 2004; Marshall and Weetman 2002; Taylor 2008).

\section{Literature Review}

Risk can be defined as the uncertainty associated with both potential gain and loss (Solomon et al. 2000), or as the difference between the actualities and the expected (Remenyi and Heafield 1996). These values reflect the magnitude of the risk. Linsley and Shrives (2006, , p.389) more specifically define risk disclosures as "any information disclosing to reader on any opportunities, prospect, hazard, harm, thread or exposure that have already impacted or may give an impact upon the company or management in future”. For comparison, finance textbooks typically define 'risk' as a set of outcomes arising from a decision that can be assigned probabilities whereas 'uncertainty' arises when probabilities cannot be assigned to the set of outcomes (Linsley and Shrives 2006). These broad definitions of risk are adopted in this study because they comprehensively embrace 'risks' and 'uncertainties'.

There are five major sub-categories for risk: 'business', 'strategy', 'operating', 'market' and 'credit' risks (Dhaliwal et al. 1983; Jorion 2000; Cabedo and Tirado 2004). Business risk is what firms willingly assume to create a competitive advantage and add value for shareholders. Business risk is symmetrical with both gains and losses for firms (Cabedo and Tirado 2004). Amit and Wernerfelt (1990) state that business risk does or should matter in strategy making due to the dual need of managers to satisfy multiple stakeholders: both as shareholders themselves and to other stakeholders (such as employees, suppliers, and surrounding community).

Strategy risk is associated with basic changes in the economy. The evolution of the economic environment generates a high level of structural economic uncertainty which affects firms' performance. Firms should therefore communicate how they are affected by changes in the economy and how sensitive the firm is to changes in these factors (Cabedo and Tirado 2004).

Operating risk arises from the risk inherent in the investment and production decisions of the firm (Dhaliwal et al. 1983). Cabedo and Tirado (2004) define operating risk as the risk of direct or indirect losses resulting from internal process errors, personnel or systems errors or from external factors faced by the firm.

Market risk can be defined as risk resulting from a variation in the price of certain economic goods (Cabedo and Tirado 2004). Hence, market risk arises from movements in the level or volatility of market prices (Jorion 2000).

Credit risk can be defined as the possibility that over time, a decrease in the real value of a firm's client portfolio may occur as a result of credit quality decadence suffered by those making up the portfolio (Cabedo and Tirado 2004).

The communication of the five major sub-categories of voluntary risk disclosures is important to provide a fundamentally better understanding of risk exposure. Higher levels of transparency will help shareholders to better understand the risks of the company (Cabedo and Tirado 2004). In addition, better disclosure can lessen the chance of market failure and increase market liquidity leading to more efficient capital markets (Healy and Palepu 2001). 


\section{Accounting Regulation}

The principal sources of accounting standards in the four countries (Indonesia, Malaysia, Singapore and Australia) are virtually identical due to the international convergence with the International Financial Reporting Standards (IFRS) (Astami and Tower 2006). IFRS refers to the entire body of International Accounting Standard Board (IASB) rules, approved by the IASB, IAS, the Standing Interpretation Committee (SIC), and its predecessor the International Accounting Standards Committee (IASC) (Astami and Tower 2006).

In the past, Indonesian accounting standards were adopted from U.S. accounting standards issued by AICPA (Craig and Diga 1996), but now, with the IFRS regulation, Indonesian companies are in the convergence process ongoing. A final decision about the ultimate target date for full compliance with IFRS is expected to be made in 2012 (IFRS 2011). In Indonesia, the standard setting body is Komite Standar Akuntansi Keuangan (Committee on Financial Accounting Standards) and there are additional disclosure requirements imposed by the Capital Market Supervisory Board (Bapepam) for listed companies (Astami and Tower 2006). Malaysian and Singaporean accounting standards are more centrally-based on accounting pronouncements of the International Accounting Standards Board (IASB). In Australia, there are required IFRS rules for all reporting entities reporting since 2005 (IFRS 2011). In summary, each of the four sample countries have implemented or are moving quickly towards full IFRS adoption.

\section{Hypothesis Development}

Prior studies document the effect of country on disclosure practice. Dye (1985), in his analytical model, suggests that voluntary communication is affected by the disclosure requirements of the accounting regime. Meek, Roberts and Gray (1995) find that country/region is one of the factors explaining the extent of voluntary disclosure. Williams and Tower (1998) examine the preferred level of disclosure in the issue of differential reporting in Singaporean and Australian small business entities, and note that small company managers in these two countries differ in their acceptance of international standards requiring higher disclosure requirements than existing domestic standards. Tower, Hancock and Taplin (1999) find that the country of reporting is the main significant factor for the level of IAS compliance in the Asia-Pacific region. Soewarso et al. (2003) also conclude that the country of incorporation is the main determinant of Australian and Singaporean disclosure practice differences. Australian companies communicate significantly more information relative to their Singaporean counterparts. Bailey, Karolyi \& Salva (2006) examine the increased disclosure for non-U.S. firms when listing shares in the U.S. and conclude that the county factor is an important determinant of increased disclosure. They note that the greatest increases are for firms from developed countries. Marshall and Weetman (2002) in a two-country comparison between the U.S. and the U.K. state that risk disclosure regulations drawn up at similar times can have a different impact in two different regulatory environments. Based on the above literature review, this paper posits country as the determinant factor explaining the association between risk disclosures. Thus, it is hypothesised that:

$H 1$ : There is an association between country of incorporation and risk disclosures in the annual reports in listed manufacturing companies.

Many prior studies (e.g., Atan and Maruhun 2009) document the significant effect of company size on disclosure practices. The level of risk information disclosures is thought to be positively associated with size (Kanto and Schadewitz 1997). Regarding the quantity of risk disclosure, Beretta and Bozzoland (2004) examine the annual reports of non-financial companies 
listed on the Italian Stock Exchange and also note a relationship with size. Similarly, Linsley and Shrives (2009) explore the association between the number of risk disclosures and company size. These studies support the hypothesis that a positive correlation exists between the volume of risk disclosures and company size. Consistent with agency theory tenets, this paper adopts company size as a potential factor explaining the positive association between risk disclosures by proposing a directional hypothesis:

H2: There is a positive association between company size and risk disclosures in the annual reports of listed manufacturing companies.

Several prior studies document the significant effect of managerial ownership on disclosure practices. Gerb (2000) examines the effect of managerial ownership on firms' disclosures and finds firms with lower levels of managerial ownership are more likely communicators of risk disclosures than firms with higher levels of managerial ownership. Eng and Mak (2003) also note a negative relationship between managerial ownership and increased disclosure. That is, based on agency theory, managers have greater incentives to consume perks and reduced incentives to maximise job performance. Thus, lower managerial ownership is associated with increased voluntary disclosure. Consistent with the results of most past studies which note a negative relationship between managerial ownership and the level of disclosure (Gerb 2000; Eng and Mak 2003), this paper advances managerial ownership as a potential factor explaining the negative association with risk disclosures by proposing a directional hypothesis:

H3: There is a negative association between managerial ownership and risk disclosures in the annual reports in listed manufacturing companies.

Prior studies document a significant effect of board independence on disclosure practices. For instance Baek, Johnson and Kim (2009) conclude that firms with a higher percentage of outside directors are more likely to disclose board and management process information, but not other types of discretionary information. Moreover, Chen and Jaggi (2000) note a positive association between the proportion of independent non-executive directors (INDs) on corporate boards of Hong Kong firms and the comprehensiveness of financial disclosures. Most studies thus conclude that INDs on corporate boards have a positive influence on management decisions to disclose financial information. Garcia-Meca and Sanches-Ballesta (2010) find a positive association between board independence and voluntary disclosures primarily in the countries with high investor protection rights. Cheng and Courtenay (2006) state that boards with a larger proportion of INDs (proxy for board-monitoring effectiveness) are significantly and positively associated with higher levels of voluntary disclosure. Beretta and Bozzoland (2004) note that different types of board directors fulfil different functions, with both the number of executive and the number of independent directors positively related to the level of corporate risk reporting. In summary, the results of most past agency theory studies establish a positive relationship between board independence and the level of disclosure (Baek et al. 2009; Chen and Jaggi 2000; Cheng and Courtenay 2006; Beretta and Bozzoland 2004; Garcia-Meca and Sanches-Ballesta 2010). Accordingly, this paper adopts the level of board independence as a potential factor explaining a positive association with risk disclosures by proposing a directional hypothesis:

H4: There is a positive association between higher levels of board independence and risk disclosures in the annual reports of listed manufacturing companies. 
This study also examines age of business, auditor, leverage and profitability as control variables to be included in the statistical analysis. These control variables are consistent with those used in prior research to add further insight (Solomon et al. 2000; Atan and Maruhun 2009; Homölle 2009; Marshall and Weetman 2002; Abraham and Cox 2007; Morrison 1993; SinclairDesgagné and Gozlan 2003; Ahmed et al. 2004; Dhaliwal et al. 1983; Cabedo and Tirado 2004; Thornton 2004; Makhija and Patton 2004; Linsley and Shrives 2009; Bremer and Pettway 2002; Lee et al. 2003; Akhigbe and Martin 2008; Xifra and Ordeix 2009).

\section{Research Approach}

A total of 180 firm years data are collected consisting of a random sample of 60 manufacturing ${ }^{4}$ listed companies' annual reports for fiscal year-ends from 2007 to 2009. The reports include 15 annual reports of manufacturing companies per country, listed in the stock exchanges of Australia, Indonesia, Malaysia and Singapore for this key three year GFC time period.

This research adopts a researcher-constructed Risk Disclosure Index (RDI) to create an index measuring the extent of risk disclosure by listed firms. In the initial stage, an extensive review of prior studies is undertaken to check for commonalities across the studies and to identify items that are linked with risk disclosures. The use of a disclosure index to measure the extent of disclosure can be traced to the work of: Solomon et al. (2000); Linsley and Shrives (2006), who synthesise The Turnbull Report; Suhardjanto (2008), who applied The Global Report Initiative (GRI); and Akhigbe and Martin (2008), who used the Sarbanes-Oxley Act as a benchmark to gouge the extent of disclosure. The Voluntary Disclosure Checklist (VDC) of Gray, Meek and Roberts (1995) and the Voluntary Disclosure Instrument (VDIS) of Ho (2009) are also used in this study to derive the benchmark disclosure checklist.

Consistent with the past literature, an equal weighting/unweighted index approach is used in scoring the RDI. The index assumes that each item of disclosure is equally important (Gray, Meek \& Roberts 1995). Overall, this simple measurement approach is considered less subjective and judgmental (Gray, Meek \& Roberts 1995).

Since the focus of this research is on voluntary risk disclosures, the preliminary disclosures checklist is first subjected to a thorough screening in order to ensure that individual items are not mandatory. This screening of the voluntary risk disclosure checklist is done with reference to the International Accounting Standards Board (IASB) mandatory risk disclosure and the mandatory risk disclosure country's rules in Indonesia, Malaysia, Singapore and Australia ${ }^{5}$. The final Risk disclosure Index (RDI) consists of 34 Risk Disclosure Index (RDI) items.

After establishing the final RDI, a scoring sheet is developed to assess the extent of voluntary risk disclosure. Consistent with past studies, the item scores one if it is disclosed and zero if it is not, subject to the applicability of the item concerning the firm.

\footnotetext{
4 The manufacturing industries in the North American Industry Classification System (NAICS) 2007 are: food; beverage and tobacco products; textile mills; textile product mills, apparel; leather and allied products; wood products; paper; printing and related support activities; petroleum and coal products; chemical, plastics and rubber products; nonmetallic mineral products; primary metal; fabricated metal products; machinery; computer and electronic products; electrical equipment; appliance and components; transportation equipment; furniture and related products; and miscellaneous manufacturing.

${ }^{5}$ The pilot study examines the possible applicability of mandatory items in IFRS 7, IFRS 9 and IAS 32. It uses 60 annual reports (5 in each country for 2007-2009). The purpose of this pilot study is to ascertain if IFRS 7 mandates disclosures which impact the RDI in the selected countries. The analysis reveals that some manufacturing companies have IFRS 7 mandatory disclosures in their annual reports. Eight items from the original 42 item variant of the Risk Disclosure Index (RDI) are mandatory and are thus removed from the initial Risk Disclosure Index (RDI). This screening leads to the final selection of the RDI disclosure items.
} 
The predictor variables are measured as follows: each of the four countries has a 'country' variable categorised as dummy; company size is calculated as total assets at the end of the financial year in U.S. dollars and logged to reduce skewness; managerial ownership is measured by percentage of managerial ownership; and board independence is the percentage of independent directors. Leverage is calculated as total liabilities divided by total assets, profitability is measured by net profit divided by total assets, and auditor is categorised as big 4 auditor or not.

\section{Findings}

The descriptive statistics for dependent variables in Table 1 shows that overall RDI scores over the economically-challenging GFC time period averages 28.61\%. It rises in 2008 but then falls slightly with the specific scores ranging from 26.91\% in 2007, 29.80\% in 2008 and $29.12 \%$ in 2009. Table 1 also reveals that business risk disclosure (40.42-42.78\%) is the highest sub-category of risk over time, while strategy risk is consistently far lower (9.79-13.75\%).

Table 1

Risk Disclosure Index Categories

\begin{tabular}{lllll}
\hline & Average & $\mathbf{2 0 0 7}$ & $\mathbf{2 0 0 8}$ & $\mathbf{2 0 0 9}$ \\
\hline Business Risk & $41.81 \%$ & $40.42 \%$ & $42.22 \%$ & $42.78 \%$ \\
Credit Risk & $36.67 \%$ & $33.33 \%$ & $37.50 \%$ & $39.17 \%$ \\
Operating Risk & $32.22 \%$ & $31.00 \%$ & $34.33 \%$ & $31.33 \%$ \\
Market Risk & $19.52 \%$ & $18.57 \%$ & $21.19 \%$ & $18.81 \%$ \\
Strategy Risk & $12.50 \%$ & $9.79 \%$ & $13.96 \%$ & $13.75 \%$ \\
\hline Total Risk Disclosure & $\mathbf{2 8 . 6 1 \%}$ & $\mathbf{2 6 . 9 1 \%}$ & $\mathbf{2 9 . 8 0 \%}$ & $\mathbf{2 9 . 1 2 \%}$ \\
Index (RDI) & & & & \\
\hline
\end{tabular}

Figure 1 illustrates that the lowest scores for all risk disclosure sub-categories is in 2007; the early year of the crisis that affected companies. For operating, market and strategy risk subcategories the highest scores are communicated in 2008, the worst year of the crisis impacting companies. For business and credit risk, the highest scores are witnessed in 2009, the year of early crisis recovery. These risk communication categories change over time. Business and credit risk disclosure consistently increase over the three year period, while operating, market and strategy risk disclosure increase in 2008, but then decrease slightly in 2009. 
Figure 1

Risk Disclosure Index Categories (2007-2009)

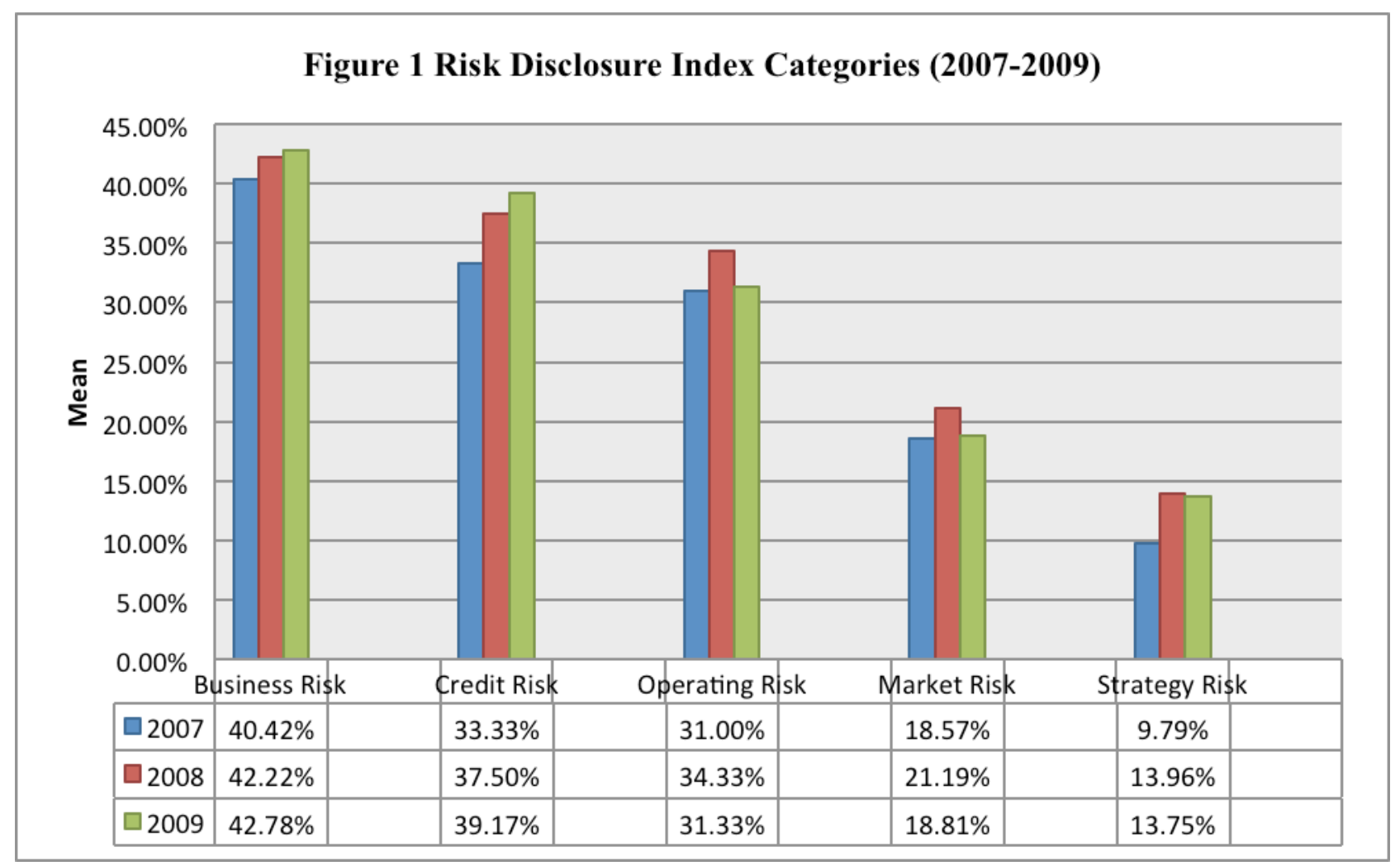

Table 2 shows that the business risk disclosure ${ }^{6}$ item "Identifying, evaluating and managing significant risks" has the highest ${ }^{7}$ level of communication (85\%), while "Cost of safety measures" is the lowest reported item (0.56\%). For the strategy risk category, "Specific external factors affecting company's prospect" is the highest item (63.33\%), while "Risks related to corruption" is the lowest item $(0.56 \%)$. For the operating risk category, "Internal control and the extent risk are acceptable" is the highest item (66.67\%), while "Internal control and impact of risks that do materialise" is the lowest item (24.4\%). For the market risk category, "Major exchange rates used in the accounts" is the highest item (94.4\%) and "Effects of inflation on assets - qualitative / quantitative" are the lowest items with no disclosure. There are only two indexes in the credit risk category. Index "Provide consumer credit business" has a higher value (67.78\%) than "Extensions of credit" (5.56\%). Overall, Table 2 reveals vast disparities of communication across the various risk elements.

\footnotetext{
${ }^{6}$ The correlations between Business Risk Disclosure Index (BRDI), Strategy Risk Disclosure Index (SRDI), Operating Risk Disclosure Index (ORDI), Market Risk Disclosure Index (MRDI), and Credit Risk Disclosure Index (CRDI) in 2007, 2008 and 2009 (table not included for brevity) reveal that all these variables have positive but not extremely high correlations. This implies that each risk category has different information content.

${ }^{7}$ ANOVA and Post hoc Tukey analysis between five sub-categories of risk (BRDI, SRDI, ORDI, MRDI and CRDI)country shows that in 2007, Australia BRDI is significantly higher than Indonesia, Malaysia ORDI is significantly higher than all three other countries and Malaysia and Singapore CRDI is significantly higher than Indonesia. For 2008, Australia BRDI is significantly higher than Indonesia, Indonesia ORDI is significantly lower than all three other countries, and Indonesia CRDI is significantly lower than all three other countries. In 2009, Australia BRDI is significantly higher than Indonesia and Indonesia ORDI is significantly lower than all three other countries (tables not included for brevity).
} 
Table 2

Risk Disclosure Index (RDI) (2007-2009)

\begin{tabular}{|c|c|c|c|c|c|c|}
\hline No & Risk Disclosure Items & Average & 2007 & 2008 & 2009 & Trend over time \\
\hline & Total Risk Disclosure Index (RDI) & $28.54 \%$ & $26.62 \%$ & $29.84 \%$ & $29.17 \%$ & Mixed \\
\hline A. & BUSINESS RISK & $41.81 \%$ & $40.42 \%$ & $42.22 \%$ & $42.78 \%$ & Rising \\
\hline \multirow[t]{2}{*}{1.} & Identifying, evaluating and managing significant & $85.00 \%$ & $81.67 \%$ & $86.67 \%$ & $86.67 \%$ & Rising \\
\hline & risks $^{\mathrm{A}}$ & & & & & \\
\hline 2. & Future prospects ${ }^{\mathrm{E}}$ & $77.22 \%$ & $76.67 \%$ & $80.00 \%$ & $75.00 \%$ & Mixed \\
\hline 3. & Effects of acquisition ${ }^{\mathrm{E}}$ & $74.44 \%$ & $71.67 \%$ & $78.33 \%$ & $73.33 \%$ & Mixed \\
\hline 4. & Effects of disposals ${ }^{\mathrm{E}}$ & $72.78 \%$ & $75.00 \%$ & $70.00 \%$ & 73.33\% & Mixed \\
\hline 5. & Impact of strategy ${ }^{\mathrm{E}}$ & $64.44 \%$ & $63.33 \%$ & $66.67 \%$ & $63.33 \%$ & Mixed \\
\hline 6. & Safety policy ${ }^{\mathrm{E}}$ & $46.67 \%$ & $43.33 \%$ & $48.33 \%$ & $48.33 \%$ & Rising \\
\hline 7. & Capital project committed $^{\mathrm{E}}$ & $27.22 \%$ & $23.33 \%$ & $25.00 \%$ & $33.33 \%$ & Large Rise \\
\hline 8. & Committed expenditure for capital projects ${ }^{\mathrm{E}}$ & $15.56 \%$ & $15.00 \%$ & $15.00 \%$ & $16.67 \%$ & Rising \\
\hline 9. & Impact of strategy on future ${ }^{\mathrm{E}^{1}}$ & $15.56 \%$ & $16.67 \%$ & $13.33 \%$ & $16.67 \%$ & Mixed \\
\hline 10. & Safety of products ${ }^{\mathrm{E}}$ & $13.33 \%$ & $10.00 \%$ & $15.00 \%$ & $15.00 \%$ & Rising \\
\hline 11. & Data on accidents ${ }^{\mathrm{E}}$ & $8.89 \%$ & $6.67 \%$ & $8.33 \%$ & $11.67 \%$ & Rising \\
\hline 12. & Cost of safety measures ${ }^{\mathrm{E}}$ & $0.56 \%$ & $1.67 \%$ & $0.00 \%$ & $0.00 \%$ & Falling \\
\hline B. & STRATEGY RISK & $12.50 \%$ & $9.79 \%$ & $13.96 \%$ & $13.75 \%$ & Mixed \\
\hline \multirow[t]{2}{*}{13.} & Specific external factors affecting company’s & $63.33 \%$ & $48.33 \%$ & $65.00 \%$ & $76.67 \%$ & Large Rise \\
\hline & prospect $^{\mathbf{D}}$ & & & & & \\
\hline 14. & Risks and opportunities due to climate change $\mathrm{e}^{\mathbf{B}}$ & $12.22 \%$ & $8.33 \%$ & $16.67 \%$ & $11.67 \%$ & Mixed \\
\hline 15. & Major regional economic development ${ }^{\mathbf{D}}$ & $10.56 \%$ & $6.67 \%$ & $15.00 \%$ & $10.00 \%$ & Mixed \\
\hline 16. & Risk-control programs regarding serious diseases $\mathbf{B}^{\mathbf{B}}$ & $7.22 \%$ & $6.67 \%$ & $8.33 \%$ & $6.67 \%$ & Mixed \\
\hline \multirow[t]{2}{*}{17.} & Risk for child labour, and elimination of child & $2.78 \%$ & $3.33 \%$ & $3.33 \%$ & $1.67 \%$ & Falling \\
\hline & labour ${ }^{\mathbf{B}}$ & & & & & \\
\hline 18. & Freedom of association risk ${ }^{\mathbf{B}}$ & $1.67 \%$ & $1.67 \%$ & $1.67 \%$ & $1.67 \%$ & No Change \\
\hline 19. & Incidents of forced or compulsory labour ${ }^{\mathbf{B}}$ & $1.67 \%$ & $1.67 \%$ & $1.67 \%$ & $1.67 \%$ & No Change \\
\hline 20. & Risks related to corruption ${ }^{\mathbf{B}}$ & $0.56 \%$ & $1.67 \%$ & $0.00 \%$ & $0.00 \%$ & Falling \\
\hline C. & OPERATING RISK & $32.22 \%$ & $31.00 \%$ & $34.33 \%$ & $31.33 \%$ & Mixed \\
\hline 21. & Internal control and the extent risk are acceptable ${ }^{\mathbf{A}}$ & $66.67 \%$ & $63.33 \%$ & $73.33 \%$ & $63.33 \%$ & Mixed \\
\hline 22. & GAAP risks of the special purpose entity ${ }^{\mathrm{C}}$ & $40.56 \%$ & $40.00 \%$ & $41.67 \%$ & $40.00 \%$ & Mixed \\
\hline 23. & Impact accounting policy changes ${ }^{\mathrm{E}}$ & $28.33 \%$ & $30.00 \%$ & $26.67 \%$ & $28.33 \%$ & Mixed \\
\hline \multirow[t]{2}{*}{24.} & Internal control, deliberation include the likelihood & $24.44 \%$ & $20.00 \%$ & $30.00 \%$ & $23.33 \%$ & Mixed \\
\hline & of risk ${ }^{\mathrm{A}}$ & & & & & \\
\hline \multirow[t]{2}{*}{25.} & Internal control and impact of risks that do & $1.11 \%$ & $1.67 \%$ & $0.00 \%$ & $1.67 \%$ & Mixed \\
\hline & materialise $^{\mathbf{A}}$ & & & & & \\
\hline D. & MARKET RISK & $19.52 \%$ & $18.57 \%$ & $21.19 \%$ & $18.81 \%$ & Mixed \\
\hline 26. & Major exchange rates used in the accounts ${ }^{\mathrm{E}}$ & $94.44 \%$ & $95.00 \%$ & $95.00 \%$ & $93.33 \%$ & Falling \\
\hline 27. & Effects of inflation on results—qualitative ${ }^{\mathrm{E}}$ & $26.11 \%$ & $23.33 \%$ & $28.33 \%$ & $26.67 \%$ & Mixed \\
\hline 28. & Effects of inflation on results—quantitative ${ }^{\mathrm{E}}$ & $6.67 \%$ & $8.33 \%$ & $8.33 \%$ & $3.33 \%$ & Falling \\
\hline 29. & Supplementary inflation adjusted financial & $6.67 \%$ & $3.33 \%$ & $10.00 \%$ & $6.67 \%$ & Mixed \\
\hline 30. & Effects of inflation on future operation-qualitative & $2.78 \%$ & $0.00 \%$ & $6.67 \%$ & $1.67 \%$ & Mixed \\
\hline 31. & Effects of inflation on assets-qualitative $\mathrm{E}^{\mathrm{E}}$ & $0.00 \%$ & $0.00 \%$ & $0.00 \%$ & $0.00 \%$ & No Disclosure \\
\hline 32. & Effects of inflation on assets—quantitative ${ }^{\mathrm{E}}$ & $0.00 \%$ & $0.00 \%$ & $0.00 \%$ & $0.00 \%$ & No Disclosure \\
\hline E. & CREDIT RISK & $36.67 \%$ & $33.33 \%$ & $37.50 \%$ & $39.17 \%$ & Rising \\
\hline 33. & Provide consumer credit business ${ }^{C}$ & $67.78 \%$ & $63.33 \%$ & $70.00 \%$ & $70.00 \%$ & Rising \\
\hline 34. & Extensions of credit ${ }^{\mathrm{C}}$ & $5.56 \%$ & $3.33 \%$ & $5.00 \%$ & $8.33 \%$ & Rising \\
\hline
\end{tabular}

Legend: A = Adapted from Turnbull Report (1999), B = Adapted from Global Report Initiative (GRI) (2006), C = Adapted from Sarbanes-Oxley Act (2002) SEC 401, D = Adapted from the Voluntary Disclosure Instrument (VDIS), Ho (2009), and E = Adapted from Voluntary Disclosure Checklist (VDC), Gray, Meek and Roberts (1995). 
Table 3 provides a summary of the descriptive statistics for the explanatory variables from the GFC period 2007-2009. Each year represents 60 companies, over the three year period of 20072009 with a total sample of 180 annual report firm years.

Table 3

Descriptive Statistics of Predictor Variables Year 2007, 2008, 2009

\begin{tabular}{lllll}
\hline Continuous & $\mathbf{2 0 0 7}$ & $\mathbf{2 0 0 8}$ & $\mathbf{2 0 0 9}$ & $\mathbf{2 0 0 7 - 2 0 0 9}$ \\
& & & & \\
\hline LogCompSize (H2) & 5.4061 & 5.4620 & 5.4561 & $\mathbf{5 . 4 4 1 4}$ \\
Size (US\$) & $\$ 1,104,000$ & $\$ 1,332,700$ & $\$ 1,272,600$ & $\mathbf{\$ 1 , 2 3 6 , 4 0 0}$ \\
ManOwn (H3) & $13.45 \%$ & $12.96 \%$ & $12.81 \%$ & $\mathbf{1 3 . 0 7 \%}$ \\
Boardind (H4) & $38.73 \%$ & $41.12 \%$ & $43.55 \%$ & $\mathbf{4 1 . 1 3 \%}$ \\
Leverage (CV) & $47.17 \%$ & $49.09 \%$ & $53.74 \%$ & $\mathbf{5 0 . 0 0 \%}$ \\
Profit (CV) & $5.56 \%$ & $-3.55 \%$ & $2.00 \%$ & $\mathbf{1 . 3 4 \%}$ \\
AgeofBus (CV) & 31.2833 & 32.2833 & 33.2833 & $\mathbf{3 2 . 2 8 3 3}$ \\
\hline
\end{tabular}

The mean of the company size in the average years is $\$ 1,236,400,000$ (total assets in U.S. dollars), increasing in 2008 but then falling slightly in 2009, and ranging from \$1,104,000,000 in 2007, \$1,332,700,000 in 2008 and \$1,272,600,000 in 2009. The lowest managerial ownership is in 2009 (12.81\%), having slowly fallen across the three year period, whereas the highest board independence occurs in 2009 (43.55\%) having risen from 38.73\% and 41.12\% in the earlier two years. The control variables also change over time. The average company financial leverage is $50.00 \%$ ranging from $47.17 \%$ to $53.74 \%$. The lowest leverage level occurs in 2007 and it increases each year. The profitability variable shows more variance as it falls in 2008 from its higher 2007 value and then rises slightly in 2009.

\section{Regression Analysis}

Table 4 shows the 2007-2009 regressions ${ }^{\mathbf{2}}$ for Business Risk Disclosure (BRDI), Credit Risk Disclosure (CRDI), Operating Risk Disclosure (ORDI), Market Risk Disclosure (MRDI) and Strategy Risk Disclosure (SRDI). This study examines the relationship between the independent variables (country, company size, managerial ownership and board independence) and control variables (profitability, leverage and auditor) with each risk category (BRDI, SRDI, ORDI, MRDI and CRDI). Table 4 illustrates the predictive power of the model from the regression in the 2007, 2008 and 2009. Key explanatory factors for risk disclosure highlighted from Table 4 are:

\footnotetext{
${ }^{8}$ Multiple regression analyses can be severely and adversely affected by failures of the data to remain constant with the assumptions that customarily accompany regression models. Mahalanobis distance and Cook's distance as diagnostic methods are available to help identify certain kinds of failure as outlier data. Diagnostics are thus valuable adjuncts to regression analyses. Mahalanobis distance and Cook's distance are capable of producing partial plots in the SPSS program. This allows for the saving of residuals (Velleman and Welsch 1981). From the residual, Mahalanobis value should be $<26.52$ (based on eight predictor variables), and Cook's value should be < 1 (Coakes and Steed 2007). Analysis shows that four companies are potential outliers (for each of their three years), and are thus dropped from the original 180 annual reports sample resulting in a final sample of 168 annual reports.
} 
- Over the three GFC years, the 'country' variable is the best predictor. It is statistically significant in 8 of 15 regressions, Australian 'business risk disclosure' (BRDI) is consistently higher than in other countries and Indonesian 'operating risk' (ORDI) tends to be lower.

- Size is a consistent positive predictor for "business risk' (BRDI) for all years and 'market risk’ (MRDI) for 2008 and 2009.

- $\quad$ There is consistently no evidence to accept the H3 hypothesis that managerial ownership is related to business risk disclosures. Table 4 shows that managerial ownership is not a predictor for any risk category in any year. Moreover, managerial ownership consistently falls over the GFC period (Table 3).

- $\quad$ Board independence is positively significant for 'business risk' (BRDI) in 2007 and 2008; and 'strategy risk' (SRDI) and 'market risk' (MRDI) in 2008 and 2009.

These Table 4 regression results for risk disclosure categories only partially support agency theory tenets (H1, H2 and H4 are only partially accepted whereas H3 is clearly rejected). The predictor variables are consistent with the previous studies: company size (Atan and Maruhun 2009; Kanto and Schadewitz 1997; Beretta and Bozzoland 2004; Linsley and Shrives 2009); and board independence (Baek et al. 2009; Chen and Jaggi 2000; Cheng and Courtenay 2006; Beretta and Bozzoland 2004; Garcia-Meca and Sanches-Ballesta 2010). Managerial ownership shows no influence - rather, the overwhelming predictor is a firm's country of ownership. Thus each country's business practices and societal expectations may be the key driving factors.

\section{Conclusion}

This study seeks to explain the categories of voluntary risk disclosure (business risk, strategy risk, operating risk, market risk and credit risk disclosure) over the turbulent Global Financial Crisis time period of 2007-2009. For the sub-categories of risk disclosures, business risk disclosure is the highest sub-category of risk over time, while strategy risk is consistently far lower (Table 1). For operating risk, market risk and strategy risk sub-categories, the highest disclosure levels occur in 2008 (the worst year of the crisis impact on companies). Yet for business risk and credit risk items, the highest communication is in 2009 (the year of crisis recovery). This implies that the increase of risk disclosure in the later years of the crisis in 2008 and 2009 reduces estimation risk to better avoid market failure and increase market liquidity leading to more efficient capital markets (Healy and Palepu 2001).

Business and credit risk disclosures rise over the three GFC years. However, operating, market and strategy risk disclosures show a different trend with each of them increasing in 2008 but then falling slightly in 2009 (see Figure 1). It is surmised that the business and strategy risk steady rises is because these issues are seen to be critically vital to the organisation's success and are thus highlighted during the economic crisis period. In contrast, operating, market and strategy risks may be perceived as being more 'competitor-sensitive' and thus extra communication of these issues may be more contingent on senior managers' perception of the depth of the crisis. As economic concerns begin to ease in 2009, the level of transparency begins to fall down to levels perhaps more comfortably in the manager's equilibrium range.

The regression analysis shows that the country, size and board independence variables partially help explain the extent of risk disclosures. The first finding is that different countries disclose differently. One plausible explanation is that the different response based on varying levels of economic development is related to the acceptance of risk information by shareholders in each country (Marshall and Weetman 2002). Secondly, bigger firms disclose more risk disclosure data. These firms are assumed to have stronger financial resources to cover the cost of communicating 
information voluntarily. Disclosure can reduce monitoring costs as part of agency costs by minimising the capacity of managers to adjust disclosure data (Marshall and Weetman 2002). Therefore, big manufacturing firms that have more complex operations will better incorporate monitoring activities to reduce asymmetry information. Thirdly, firms with better corporate governance systems at times communicate more risk information. Greater presence of independent directors within the company can positively affect the risk disclosure levels (Beretta and Bozzoland 2004). Arguably, independent directors have less personal interests which allow them to press for better communication to the shareholders about risk information. In addition, independent directors have incentives to exercise their decision control to maintain reputational capital. Finally, managerial ownership does not influence the level of risk disclosure. Managers in these firms lowered their ownership steadily over the study period and thus may be a lesser influence (Table 3).

Overall, this study finds that there are varying levels of risk disclosure categories over time and across countries, and such communication is partially influenced by key firm characteristics and economic drivers mostly in line with agency theory tenets. 
Table 4

Result of Full Regressions of 5 RDI factors

\begin{tabular}{|c|c|c|c|c|c|c|c|c|c|c|c|c|c|c|c|}
\hline & $\begin{array}{l}\text { BRDI } \\
\text { 07 }\end{array}$ & $\begin{array}{l}\text { SRDI } \\
07\end{array}$ & $\begin{array}{l}\text { ORDI } \\
\text { 07 }\end{array}$ & $\begin{array}{l}\text { MRDI } \\
\text { 07 }\end{array}$ & $\begin{array}{l}\text { CRDI } \\
07\end{array}$ & $\begin{array}{l}\text { BRDI } \\
08\end{array}$ & $\begin{array}{l}\text { SRDI } \\
08\end{array}$ & $\begin{array}{l}\text { ORDI } \\
08\end{array}$ & $\begin{array}{l}\text { MRDI } \\
08\end{array}$ & $\begin{array}{l}\text { CRDI } \\
08\end{array}$ & $\begin{array}{l}\text { BRDI } \\
09\end{array}$ & $\begin{array}{l}\text { SRDI } \\
09\end{array}$ & $\begin{array}{l}\text { ORDI } \\
09\end{array}$ & $\begin{array}{l}\text { MRDI } \\
09\end{array}$ & $\begin{array}{l}\text { CRDI } \\
09\end{array}$ \\
\hline Cty & $\begin{array}{l}\mathbf{0 . 0 0 1} \\
*\end{array}$ & 0.410 & $\begin{array}{l}\mathbf{0 . 0 0 2} \\
*\end{array}$ & 0.485 & $\begin{array}{l}0.005 \\
*\end{array}$ & 0.187 & $\begin{array}{l}(-) \\
0.815\end{array}$ & $\begin{array}{l}0.002 \\
*\end{array}$ & 0.584 & $\begin{array}{l}\mathbf{0 . 0 3 7} \\
* *\end{array}$ & $\begin{array}{l}0.006 \\
*\end{array}$ & 0.815 & $\begin{array}{l}\mathbf{0 . 0 1 2} \\
* *\end{array}$ & 0.154 & $\begin{array}{l}\mathbf{0 . 0 8 3} \\
* * *\end{array}$ \\
\hline Size & $\begin{array}{l}\mathbf{0 . 0 0 1} \\
*\end{array}$ & 0.944 & $\begin{array}{l}(-) \\
0.963\end{array}$ & 0.207 & 0.431 & $\begin{array}{l}\mathbf{0 . 0 0 4} \\
*\end{array}$ & 0.350 & 0.443 & $\begin{array}{l}\mathbf{0 . 0 7 7} \\
* * *\end{array}$ & 0.324 & $\begin{array}{l}\mathbf{0 . 0 1 6} \\
* *\end{array}$ & 0.202 & $\begin{array}{l}(-) \\
0.666\end{array}$ & $\begin{array}{l}\mathbf{0 . 0 8 2} \\
* * *\end{array}$ & 0.292 \\
\hline $\begin{array}{l}\text { Man } \\
\text { Own }\end{array}$ & $\begin{array}{l}(-) \\
0.448\end{array}$ & $\begin{array}{l}(-) \\
0.671\end{array}$ & $\begin{array}{l}(-) \\
0.173\end{array}$ & 0.274 & $\begin{array}{l}(-) \\
0.290\end{array}$ & 0.862 & 0.942 & 0.928 & 0.289 & 0.350 & $\begin{array}{l}(-) \\
0.888\end{array}$ & 0.163 & $\begin{array}{l}(-) \\
0.569\end{array}$ & 0.712 & 0.679 \\
\hline $\begin{array}{l}\text { Board } \\
\text { Ind }\end{array}$ & $\begin{array}{l}\mathbf{0 . 0 0 3} \\
*\end{array}$ & 0.532 & 0.646 & 0.703 & 0.505 & $\begin{array}{l}\mathbf{0 . 0 0 7} \\
*\end{array}$ & $\begin{array}{l}0.008 \\
*\end{array}$ & 0.716 & $\begin{array}{l}\mathbf{0 . 0 2 7} \\
* *\end{array}$ & 0.870 & 0.198 & $\begin{array}{l}\mathbf{0 . 0 9 2} \\
* * *\end{array}$ & $\begin{array}{l}(-) \\
0.768\end{array}$ & $\begin{array}{l}\mathbf{0 . 0 2 9} \\
* *\end{array}$ & 0.549 \\
\hline Lev & $\begin{array}{l}(-) \\
0.005 \\
*\end{array}$ & $\begin{array}{l}(-) \\
0.806\end{array}$ & $\begin{array}{l}(-) \\
0.073 \\
* * *\end{array}$ & $\begin{array}{l}(-) \\
0.432\end{array}$ & $\begin{array}{l}(-) \\
0.794\end{array}$ & $\begin{array}{l}(-) \\
0.021 \\
* *\end{array}$ & $\begin{array}{l}(-) \\
0.741\end{array}$ & 0.150 & $\begin{array}{l}(-) \\
0.101\end{array}$ & $\begin{array}{l}(-) \\
0.934\end{array}$ & $\begin{array}{l}(-) \\
0.205\end{array}$ & $\begin{array}{l}(-) \\
0.585\end{array}$ & $\begin{array}{l}(-) \\
0.450\end{array}$ & $\begin{array}{l}\mathbf{0 . 0 3 2} \\
* *\end{array}$ & $\begin{array}{l}(-) \\
0.613\end{array}$ \\
\hline Profit & 0.989 & $\begin{array}{l}\mathbf{0 . 0 1 6} \\
* *\end{array}$ & 0.557 & 0.170 & $\begin{array}{l}(-) \\
0.927\end{array}$ & 0.672 & 0.180 & $\begin{array}{l}\mathbf{0 . 0 7 2} \\
* * *\end{array}$ & $\begin{array}{l}(-) \\
0.836\end{array}$ & 0.148 & $\begin{array}{l}(-) \\
0.887\end{array}$ & 0.167 & 0.753 & 0.399 & $\begin{array}{l}(-) \\
0.964\end{array}$ \\
\hline Audit & 0.669 & 0.705 & 0.394 & $\begin{array}{l}(-) \\
0.619\end{array}$ & $\begin{array}{l}(-) \\
0.902\end{array}$ & 0.446 & 0.730 & $\begin{array}{l}\text { 0.031 } \\
* *\end{array}$ & $\begin{array}{l}(-) \\
0.718\end{array}$ & 0.158 & 0.676 & 0.488 & 0.386 & 0.490 & 0.648 \\
\hline Age & 0.696 & 0.291 & 0.347 & 0.654 & $\begin{array}{l}(-) \\
0.523\end{array}$ & 0.688 & 0.397 & 0.534 & 0.140 & 0.552 & 0.851 & 0.431 & 0.500 & 0.175 & 0.327 \\
\hline $\begin{array}{l}\text { Adj R } \\
\text { Square }\end{array}$ & $31.9 \%$ & $12.4 \%$ & $16.6 \%$ & $12.9 \%$ & $4.9 \%$ & $21.5 \%$ & $10.8 \%$ & $17.5 \%$ & $10.9 \%$ & $1.7 \%$ & $15.5 \%$ & $3.1 \%$ & $6.7 \%$ & $12.1 \%$ & $4.7 \%$ \\
\hline
\end{tabular}

Legend: *Highly significant at $1 \%$ level, **significant at 5\% level, ***significant at $10 \%$ level, $\mathrm{n}=168$ (180 - 12 outliers)

BRDI: Business Risk Disclosure, SRDI: Strategy Risk Disclosure, ORDI: Operating Risk Disclosure, MRDI: Market Risk Disclosure, CRDI: Credit Risk Disclosure. 


\section{References}

Abraham, S., and P. Cox. 2007. Analysing the Determinants of Narrative Risk Information in UK FTSE 100 Annual Reports. The British Accounting Review 39 (3):227-248. http://dx.doi.org/10.1016/j.bar.2007.06.002

Ahmed, A. S., A. Beatty, and B. Bettinghaus. 2004. Evidence on the Efficacy of Interest-Rate Risk Disclosures by Commercial Banks. The International Journal of Accounting 39 (3):223 - 251. http://dx.doi.org/10.1016/j.intacc.2004.06.002

Akhigbe, A., and A. D. Martin. 2008. Influence of Disclosure and Governance on Risk of US Financial Services Firms Following Sarbanes-Oxley. Journal of Banking \& Finance 32 (10):2124-2135. http://dx.doi.org/10.1016/j.jbankfin.2007.12.037

Amit, R., and B. Wernerfelt. 1990. Why do firms reduce business risk? Academy of Management Journal 33 (3):520-533. http://dx.doi.org/10.2307/256579

Astami, E. W., and G. Tower. 2006. Accounting-Policy Choice and Firm Characteristics in the Asia Pacific Region: An International Empirical Test of Costly Contracting Theory. The International Journal of Accounting 41 (1):1-21. http://dx.doi.org/10.1016/j.intacc.2005.12.004

Atan, R., and E. N. S. Maruhun. 2009. Coorporate Transparency in Disclosing Risk Amongst Malaysian Companies. In European Applied Business Research Conference (EABR) and The college Teaching and Learning Conference (TLC). Conference proceding. Prague, Czech Republic.

Baek, H. Y., D. R. Johnson, and J. W. Kim. 2009. Managerial Ownership, Coorporate Governance, and Voluntary Disclosure. Journal of Business and Economic Studies 15 (2):44-61.

Bailey, W., G. Andrew Karolyi, and C. Salva. 2006. The Economic Consequences of Increased Disclosure: Evidence from International Cross-Listings. Journal of Financial Economics 81 (1):175-213. http://dx.doi.org/10.1016/j.jfineco.2005.06.002

Beretta, S., and S. Bozzoland. 2004. A Framework for the Analysis of Firm Risk Communication. The International Journal of Accounting 39 (3):265-288.

http://dx.doi.org/10.1016/j.intacc.2004.06.006

Bremer, E., and R. H. Pettway. 2002. Information and the Market's Perceptions of Japanese Bank Risk: Regulation, Environment,and Disclosure. Pacific-Basin Finance Journal 10 (2):119 - 139. http://dx.doi.org/10.1016/S0927-538X(01)00033-6

Cabedo, J. D., and J. M. Tirado. 2004. The Disclosure of Risk in Financial Statement. Accounting Forum 28 (2):181-200. http://dx.doi.org/10.1016/j.accfor.2003.10.002

Chen, C. J. P., and B. Jaggi. 2000. Association between Independent Non-Executive Directors, Family Control and Financial Disclosures in Hong Kong. Journal of Accounting and Public Policy 19 (45):285-310. http://dx.doi.org/10.1016/S0278-4254(00)00015-6

Cheng, E. C. M., and S. M. Courtenay. 2006. Board Composition, Regulatory Regime and Voluntary Disclosure. The International Journal of Accounting 41 (3):262-289. http://dx.doi.org/10.1016/j.intacc.2006.07.001

Claessens, S., M. Ayhan Kose, and M. E. Terrones. 2010. The Global Financial Crisis: How Similar? How Different? How Costly? Journal of Asian Economics 21 (3):247-264. http://dx.doi.org/10.1016/j.asieco.2010.02.002

Coakes, S., and L. Steed. 2007. SPSS: Analysis without anguish: Version 14.0 for Windows: Milton: John Wiley \& Sons Australia.

Craig, R. J., and J. G. Diga. 1996. Financial Reporting Regulation in ASEAN: Features and Prospects. The International Journal of Accounting 31 (2):239-259. http://dx.doi.org/10.1016/S0020-7063(96)90006-0

Dhaliwal, D. S., F. M. Mboya, and R. M. Barefield. 1983. Utilization of SFAS No.14 Disclosures in Assessing Operating Risk. Journal of Accounting and Public Policy 2 (2):83-98. http://dx.doi.org/10.1016/0278-4254(83)90002-9

Dye, R. A. 1985. Strategic Accounting Choice and the Effects of Alternative Financial Reporting Requirements. Journal of Accounting Research 23 (2):544-574. http://dx.doi.org/10.2307/2490826

Eng, L. L., and Y. T. Mak. 2003. Corporate Governance and Voluntary Disclosure. Journal of Accounting and Public Policy 22 325-345. http://dx.doi.org/10.1016/S0278-4254(03)00037-1 
FASB. Summary of Statement No. 133. Accounting for Derivative Instruments and Hedging Activities (Issued 6/98) 1998 [cited 17 January 2011. Available from http://www.fasb.org/summary/stsum133.shtml.

Garcia-Meca, E., and J. P. Sanches-Ballesta. 2010. The Association of Board Independence and Ownership Concentration with Voluntary Disclosure: A Meta-analysis. European Accounting Review 19 (3):603-627. http://dx.doi.org/10.1080/09638180.2010.496979

Gerb, D. S. 2000. Managerial ownership and accounting disclosure: an empirical study. Review of Quantitative Finance and Accounting. 15 (2):169-185. http://dx.doi.org/10.1023/A:1008321230900

Gray, S. J., G. Meek, and C. B. Roberts. 1995. International capital market pressure and voluntary disclosure by U.S and U.K. multinationals. Journal of International Financial Management and Accounting. 6 (1):43-68. http://dx.doi.org/10.1111/j.1467-646X.1995.tb00049.x

Healy, P. M., and K. G. Palepu. 2001. Information asymmetry, corporate disclosure, and the capital markets: A review of the empirical disclosure literature. Journal of Accounting and Economics 31 (1-3):405440. http://dx.doi.org/10.1016/S0165-4101(01)00018-0

Hill, P., and H. Short. 2009. Risk disclosures on the second tier markets of the London Stock Exchange. Accounting and Finance. 49 (4):753-780. http://dx.doi.org/10.1111/j.1467-629X.2009.00308.x

Ho, P. L. 2009. Determinants of voluntary disclosure by Malaysian listed companies over time. Unpublised Doctoral Thesis, Curtin University of Technology, Perth Australia.

Homölle, S. 2009. Bank capital regulation, asset risk, and subordinated uninsured debt. Journal of Economics and Business 56 (6):443-468. http://dx.doi.org/10.1016/j.jeconbus.2004.06.002

IASB. Presentation of financial statement. 2008 [cited 10 December 2009. Available from http://www.iasb.org/NR/rdonlyres/ A78BAF78-21F7-42C4-B8D5-D13EDBEFC786/0/IAS1.pdf.

IFRS. The Move Toward Global Standard 2011 [cited 20 Mei 2011. Available from http://www.ifrs.org/Use+around+the+world/Use+around+the+world.htm.

IMF. International Monetary Fund, world economic outlook database October 20092009 [cited 25 January 2010. Available from http://www.imf.org/external/pubs/ft/weo/2009/02/weodata.

Jensen, M. C., and W. H. Meckling. 1976. Theory of the firm: managerial behaviour, agency costs and ownership structure. Journal of Financial Economics 3 (3):305-360. http://dx.doi.org/10.1016/0304-405X(76)90026-X

Jorion, P. 2000. Value, risk and control: a dynamic process in need of integration. Financial Times, May 16, 10.

Kanto, A. J., and H. J. Schadewitz. 1997. A multidimensional model for the disclosure policy of firm. Scandinavian Journal of Management. 13 (3):229-249. http://dx.doi.org/10.1016/S09565221(97)00007-9

Kenc, T., and S. Dibooglu. 2009. The 2007-2009 financial crisis, global imbalances and capital flows: Implications for reform. Economic Systems In Press, Corrected Proof.

Lee, P., D. Stokes, S. Taylor, and T. Walter. 2003. The association between audit quality, accounting disclosures and firm-specific risk: Evidence from initial public offerings Journal of Accounting and Public Policy 22 (5):377-400. http://dx.doi.org/10.1016/j.jaccpubpol.2003.08.003

Linsley, P. M., and P. J. Shrives. 2006. Risk reporting: a study of risk disclosure in the annual reports of UK companies. The British Accounting Reviews 38 (4):387-404. http://dx.doi.org/10.1016/j.bar.2006.05.002

Linsley, P. M., and P. J. Shrives. 2009. mary Douglas, risk and accounting failures. Critical Perspectives on Accounting 20 (4):492-508. http://dx.doi.org/10.1016/j.cpa.2008.05.004

Loser, C. M. 2009. Global financial turmoil and Emerging Market Economies: Major contagion and a shocking loss of wealth? South Asia Forum on the Impact of Global Economic and Financial Crisis: Asian Development Bank.

Makhija, A., and J. Patton. 2004. The impact of firm ownership structure on voluntary disclosure: Empirical evidence from Czech annual reports. Journal of Business and Economic Studies 77 (3):457-491.

Marshall.A.P, and Weetman.P. 2002. Information asymmetry in disclosure of foreign exchange risk management: Can regulation be effective? Journal of Economics and Business 54 (1):31-53. http://dx.doi.org/10.1016/S0148-6195(01)00058-3

Meek, G. K., C. B. Roberts, and S. J. Gray. 1995. Factor influencing voluntary annual report disclosure by U.S., U.K. and continental European multinational corporations. Journal of International Business Studies 26 (3):555-572. http://dx.doi.org/10.1057/palgrave.jibs.8490186 
Mishkin, F. S. 2011. Over the Cliff: From the Subprime to the Global Financial Crisis. Journal of Economic Perspectives 25 (1):49-70. http://dx.doi.org/10.1257/jep.25.1.49

Morrison, E. R. 1993. Off-balance sheet risk: What are they and why is their disclosure important? Journal of Accounting Education 11 (2):313-320. http://dx.doi.org/10.1016/0748-5751(93)90011-7

Remenyi, D., and A. Heafield. 1996. Business process re-engineering: some aspects of how to evaluate and manage the risk exposure. International Journal of Project Management 14 (6):349-357. http://dx.doi.org/10.1016/0263-7863(96)00013-0

Sarbanes Oxley Act. PUBLIC LAW 107-204 2002 [cited 4 January 2010. Available from www.gpo.gov80/fdsys/pkg/PLAW-107publ204/pdf/PLAW-107publ204.

Sinclair-Desgagné, B., and E. Gozlan. 2003. A Theory of Environmental Risk Disclosure. Journal of Environmental Economics and Management 45 (2, Supplement 1):377-393.

Soewarso, E., G. Tower, P. Hancock, and R. Taplin. 2003. A comparative study of de jure and de facto disclosure between Australia and Singapore. Asia Review of Accounting 11 (1):18-47. http://dx.doi.org/10.1108/eb060761

Solomon, J. F., A. Solomon, S. Norton, and N. Joseph. 2000. A conceptual framework for corporate risk disclosure emerging from the agenda for corporate governance reform. British Accounting Review 32 (4):447-478. http://dx.doi.org/10.1006/bare.2000.0145

Suhardjanto, D. 2008. Environmental reporting practices: an empirical study in Indonesia. Unpublised Doctoral Thesis, Curtin University of Technology, Perth Australia.

Taylor, G. J. 2008. Determinants of financial instrument disclosure pattern of Australian listed resource firms pre- and post- IFRS adoption. Unpublised Doctoral Thesis, Curtin University of Technology, Perth Australia.

Thornton, D. B. 2004. Discussion of "evidence on the efficacy of interest rate risk disclosure by commercial bank”. The International Journal of Accounting 39 (3):257-263. http://dx.doi.org/10.1016/j.intacc.2004.06.004

Tower, G., P. Hancock, and R. H. Taplin. 1999. A regional study of listed companies' compliance with international accounting standards. Accounting Forum 23 (3):293-305.

http://dx.doi.org/10.1111/1467-6303.00016

Turnbull Report. Turnbull Report, Internal Control, Guidance for directors on the combined code 1999 $\begin{array}{llllll}\text { [cited } & 15 & \text { October } & 2009 . & \text { Available } & \text { from }\end{array}$ http://www.icaew.com/index.cfm/route/120907/icaew ga/pdf.

Velleman, P. F., and R. E. Welsch. 1981. Efficient Computing of Regression Diagnostics. The American Statistician 35 (4):234-242.

Williams, S. M., and G. Tower. 1998. Differential reporting in Singapore and Australia: A small business managers' perspective. The International Journal of Accounting 33 (2):263-268. http://dx.doi.org/10.1016/S0020-7063(98)90029-2

World Bank. World Development Indicator 2011 [cited 28 October 2011. Available from http://data.worldbank.org/data-catalog/world-development-indicators.

Xifra, and Ordeix. 2009. Managing reputational risk in an economic downturn: The case of Banco Santander. Public Relations Review 35 (4):353-360.

http://dx.doi.org/10.1016/j.pubrev.2009.08.004 